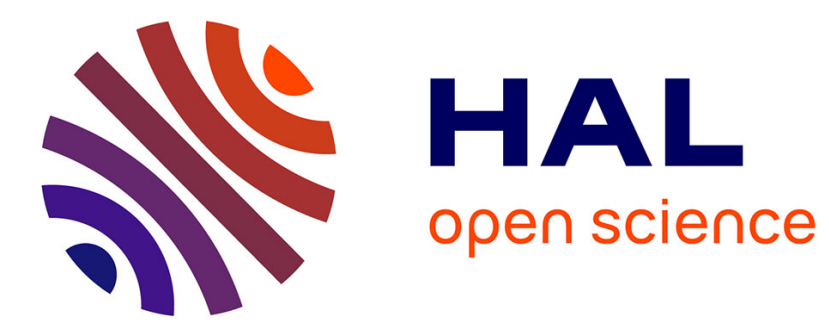

\title{
Corporate disclosure: a review of its (direct and indirect) benefits and costs
}

Etienne Farvaque, Catherine Refait-Alexandre, Dhafer Saïdane

\section{To cite this version:}

Etienne Farvaque, Catherine Refait-Alexandre, Dhafer Saïdane. Corporate disclosure: a review of its (direct and indirect) benefits and costs. 2016. hal-01391688

\section{HAL Id: hal-01391688 \\ https://hal.science/hal-01391688}

Preprint submitted on 9 Nov 2016

HAL is a multi-disciplinary open access archive for the deposit and dissemination of scientific research documents, whether they are published or not. The documents may come from teaching and research institutions in France or abroad, or from public or private research centers.
L'archive ouverte pluridisciplinaire HAL, est destinée au dépôt et à la diffusion de documents scientifiques de niveau recherche, publiés ou non, émanant des établissements d'enseignement et de recherche français ou étrangers, des laboratoires publics ou privés. 


\title{
CORPORATE DISCLOSURE:
}

\section{A REVIEW OF ITS (DIRECT AND INDIRECT) BENEFITS AND COSTS}

\author{
Etienne Farvaque;, Catherine Refait-Alexandre*, Dhafer Saïdane*
}

\begin{abstract}
This paper reviews the literature on corporate disclosure. Policymakers often support corporate disclosure but more contrasted views have emerged in the academic literature, showing that even if disclosure can actually benefits to shareholders, it is costly and it may trigger pernicious effects. Disclosing information is expensive (communication and audit costs, competitors access strategic information, and induced managers' suboptimal behavior). It also generates informational costs, as firms can disclose false, manipulated, too complex or too extensive information. And disclosure can reduce actors' incentives to look for information about the firm, and therefore can lead to an (potentially destabilizing) illusion of knowledge.
\end{abstract}

Keywords: Disclosure; Governance; Financial Stability

JEL Classification: G10, G30

Résumé : Cet article présente la littérature relative à la transparence des entreprises. La transparence apparaît souvent comme souhaitable voire nécessaire dans les discours des responsables politiques. La littérature académique est néanmoins plus nuancée : elle montre que même si une divulgation d'informations accrue de la part des entreprises a souvent des effets bénéfiques, notamment pour les actionnaires, elle engendre néanmoins des coûts et peut avoir des effets pervers. Divulguer de l'information est coûteux (coûts d'audit et de diffusion, comportement sous-optimal des dirigeants). La transparence induit aussi des coûts informationnels : les entreprises peuvent divulguer des informations fausses, manipulées, trop complexes ou trop nombreuses. Et la transparence peut réduire les incitations des acteurs en présence à chercher de l'information relative à l'entreprise, pouvant ainsi créer une illusion de connaissance potentiellement déstabilisatrice.

\footnotetext{
- EDEHN - Université du Havre \& Skema Business School

Faculté des Affaires Internationales, Université du Havre, 25 rue Philippe Lebon BP 112376063 Le Havre Cedex (France) Tél.: (33) 2744031 12, etienne.farvaque@univ-lehavre.fr

- CRESE, Université de Franche Comté

45 Avenue de l'Observatoire 25000 Besançon (France) Tél: (33) 3816667 59, catherine.refait-alexandre@univfcomte.fr

• EQUIPPE-Universités de Lille Nord de France and Skema Business School Université Charles de Gaulle Lille 3, 14 place Bodart Timal - BP 44759058 ROUBAIX cedex 0, Tel : 03.20.41.74.00 dhafer.saidane@univ-lille3.fr.
} 
Mots-clefs : Transparence, communication, gouvernance, stabilité financière 


\section{Introduction}

Media are not shy at reporting corporate frauds, be they debt concealment, false announcements of good results, and manipulation of all kinds of information, which often coincides with the end of financial fads or the bursting of bubbles. These malpractices have been considered as proof of the failure of the then prevailing models of corporate governance, and of the dangers of a lack of disclosure. Since then, regulation, in Europe and across the Atlantic, has responded by attempting to impose new mechanisms of governance and by requesting from firms more information obligations, and better controls of information, notably through the Sarbanes-Oxley Act in 2002 in the United States. Transparency has in particular been put forward in the banking sector: the pillar 3 of Basel II requires disclosure to enhance market discipline. Lack of disclosure is once again considered as lying at the heart of the current crisis, with opacity affecting above all investment banks. And, from the very beginning of the crisis, increased transparency has been seen as one of the main elements of an improved financial regulation. G20 major economies have notably highlighted the dominant role of transparency in measures to fight the crisis and avoid a potential repetition (see G20, 2007 and 2009). The manipulation of information, via the complexity of structured products resold in the markets, and plain fraud, are again being investigated. Moreover, the mandate of the new Financial Stability Board, created by G20 countries in April 2009, contains a requirement for its members to maintain the transparency of the financial sector.

Information asymmetry between the firm or the bank and third parties, whether these are investors, creditors, employees or the public authorities, can thus safely be considered as one of the main culprits of financial and economic crises and, as such, lies at the heart of actors' concerns. Disclosure, whether voluntary or mandatory, would have the virtue of reducing information asymmetries and of allowing effective control of managers, and (re-)establishing good governance. In sum, though the problem is not new, the current crisis has installed transparency, and thus disclosure, as a one-stop shopping solution. Is such a position justified?

The problems of information asymmetry have long been highlighted in the literature, in particular in the corporate finance literature (Berle and Means, 1932, Jensen and Meckling, 1976). These information asymmetries oppose the manager and the shareholders, or, following a broader view, they oppose on the one hand those who are commonly called insiders (managers and majority shareholders) and, on the other hand, the outsiders (minority shareholders, creditors, and other stakeholders). One could also include the regulatory authorities among these outsiders, as well as information professionals - the rating agencies and financial analysts. As part of a separation between the ownership of capital and control, information asymmetries pose the problem of the ex post control of the choices of managers by shareholders. The response provided by the traditional 
literature related to corporate governance was the definition and implementation of incentive contracts. These were supposed to solve the following two problems: first, the cost of perfect information and, second, the inability of shareholders to process information correctly (which is the major reason for delegating power). However, incentive mechanisms, whose objectives are to make manager's interests coincide with those of shareholders, have shown their pernicious effects (see in particular Shleifer and Vichny, 1997, and witness the Enron scandal). Since the 1990s and the first decade of the 21 st century, then, the solution to the problem of information asymmetry seems to be disclosure, supported by an apparent consensus between economic actors, public authorities and the media. However, the academic literature is more qualified. The costs of establishing disclosure are well known, and are the justification of the existence of a second-best equilibrium: the first best, in perfect information, has long been assumed unattainable. The drawbacks of perfect information, or, at the least, of information disclosure, have been enlightened (see e.g. Hirshleifer, 1971). For instance Prat (2005) and Crémer (1995) show that reducing informational asymmetries between an agent and a principal does not necessary improve the principal's utility or profit. Knowledge reduces the principal's will to punish the agent even though it would be necessary to increase efficiency (Crémer, 1995). The disclosure of information to third parties reduces the incentive of agents to behave for the principal's sake (Prat, 2005). So, quite logically, the costs of establishing corporate disclosure on financial markets, and the pernicious effects of it, have increasingly been highlighted by the modifications of regulation, laws, rules and behaviors.

A rich empirical literature on the consequences of corporate disclosure on financial markets has grown rapidly. This literature focuses on disclosure for listed companies first because these companies are the more acutely concerned, and, second, because the new legislations were intended mostly for them. It has to be precised that most of these studies relate to recent U.S regulatory events, as the introduction of the Sarbanes Oxley Act and the SEC's Regulation Fair Disclosure. So one may quickly lose touch with the main lessons it provides, especially if one is not a specialist in the field. The objective of this article is thus to organize this new literature and review its main conclusions. We focus on the recent empirical literature considering the consequences of corporate disclosure on financial markets. We present the benefits of disclosure, but we focus on the costs of disclosure to point out that, even if disclosure brings benefits, its costs should induce one to be careful of too much disclosure. Not only has disclosure drawbacks per se (i.e., transparency is not always intrinsically desirable), but it also appears that other drawbacks can be generated by an imperfect design of the regulation on disclosure.

This review distinguishes itself from the existing ones by the adoption of an economist's point of view on this topical issue. More precisely, our perspective is to look at the issue from an economic 
policy perspective, while Leuz and Wysocki (2008), for example, consider the issue from the accounting, economic, financial and legal perspectives, a view too broad to grasp for an economist (or any interested reader) not acquainted with the issue. Our argument is that, presently, both the media and the policy-makers present transparency as a panacea to avoid financial crisis in the future, whereas the academic literature is more qualified. We particularly underline the important informational problems surrounding the issue, up to the paradox that too much information may kill information. In other words, we provide a skeptical guide to the present political emphasis on transparency as a panacea to real world crises. ${ }^{1}$

As a background to the discussion, we start by defining disclosure, and the different forms it can take. We then turn to the benefits of disclosure, before considering the costs of disclosure, emphasizing the costs for the firm first. Then we focus on the fact that the disclosure, voluntarily or compulsorily, can paradoxically reduce the available information. These costs are related to informational issues. The last part synthesizes our results and concludes.

\section{Defining corporate disclosure}

Corporate disclosure can be defined as the communication of information by people inside the public firms towards people outside ${ }^{2}$. The main aim of corporate disclosure is "to communicate firm performance and governance to outside investors" (Haely and Palepu, 2001). This communication is not only called for by shareholders and investors to analyze the relevance of their investments, but also by the other stakeholders, particularly for information about corporate social and environmental policies.

Disclosure takes different forms. The first one is financial reporting, essentially financial statements whose contents are defined by accounting standards (for instance the International Financial Reporting Standards). As compliance with good practice in corporate governance is now required, reporting also concerns governance (for instance, the "comply or explain" principle has been enforced since 2008 in the European Union). Reporting must respect specific rules, even specific formats, restricting the discretion of managers, and allowing stakeholders a better understanding of information. Besides reporting, managers also communicate information in a less formal way, for instance by press conferences, by announcement on Internet sites and so on.

\footnotetext{
${ }^{1}$ Other important surveys on the consequences of disclosure include Vishwanath and Kaufmann (1999), for the macroeconomic level, and Verrecchia (2001), with a more microeconomic orientation. Leuz and Wysocki (2008) insist on the interactions between accounting rules and disclosure requirements with other securities regulations and institutional factors within a country and across markets.

${ }^{2}$ Note that one of the difficulties one meets is that many definitions of disclosure are used in the academic literature, as authors generally adapt definitions to the specific contexts they study.
} 
Whatever the form the disclosure takes, two other distinctions can be done. The first distinction is based on the opposition between financial and non-financial disclosure. The latter includes information relating to the company's social and environmental responsibility and company's corporate governance as well as information relating to the firm's operating methods or to managers' health (Healy and Palepu, 2001). The second distinction is based on the opposition between voluntary and mandatory disclosure. Voluntary disclosure is a measure of self-regulation or a response to the expectations of stakeholders and civil society for more disclosure (Chandler, 1997). Mandatory disclosure results from legislation or regulation.

In order to empirically assess the benefits or the costs of disclosure, it is necessary to compare different levels of disclosure. Some authors make inter-firms comparison, assuming that in the same country, in the same year, some companies disclose more or better than the other ones (for instance Botosan, 2000 or Patel and Dallas, 2002). Others use inter-temporal (Akhibe and Martin, 2006) or international (for instance Bhat et al. 2006) comparisons, assuming that some regulations or laws lead to higher level of disclosure.

A firm can increase its level of disclosure in different ways. First, the quantity of information disclosed may be higher. For instance, the European Transparency Directive ${ }^{3}$ requires more intermediate information: a biannual financial report and activity report, and detailed quarterly publications, including financial information e.g. the revenue and the earnings. The Sarbanes-Oxley Act, which has applied to all companies listed in the US market since 2002, required the disclosure of "all material off-balance sheet transactions, arrangements, obligations (...) that may have a material current or future effect on financial condition (...)" (see Section 401 of Sarbanes-Oxley Act). Another example is the governance disclosure and the CSR (Corporate Social Responsibility) disclosure. For instance, in France, the "Sécurité Financière" law requires a governance report for public companies. The law on the "Nouvelles Réglementations Economiques" requires information about how the public companies take care about economic and social consequences of their activities. Second, the disclosure may be more frequent. For instance, the general regulation of AMF (the French Financial Market Authority) demands the disclosure of permanent information: any information that could influence the share price. And the manager may decide to give more interviews or to organize meetings with financial analysts. Third, the information disclosed may be more easily available. The general regulation of AMF demands that the regulated information are disclosed on the company website and on all the medias. Finally, the quality of the information

\footnotetext{
${ }^{3}$ Directive $n^{\circ} 2004 / 109-15^{\text {th }}$ December 2004. Its aim is to enhance transparency on European capital markets.

${ }^{4}$ Law n ${ }^{\circ} 2003-706-1^{\text {st }}$ August 2003.

${ }^{5}$ Law n $^{\circ} 2001-420-15$ th May 2001.
} 
disclosed may be enhanced; it was one of the main objectives of the Sarbanes-Oxley Act. For instance the respect of good practices in corporate governance as the requirement of extern independent auditors may play an important role (See e.g. Forker, 1992, Romano, 2005 or Akhigbe and Martin, 2006). More generally the quality of disclosure can be improved by a better internal control or external conctrol, as required by the Sarbanes Oxley Act. The accounting standards play an important role. The international normalization, thanks to the creation of the IFRS (International Financial Reporting Standards), allows for a better clarity, comparability and understanding of the financial reports by the outsiders, in particular the non-professional shareholders. Furthermore, the IFRS increase the quality of disclosure thanks to the concept of fair-value (or market-to-market value): assets and liabilities have to be measured by their market value instead of their historical value for instance (see Leuz and Verrecchia, 2000).

To sum up, a greater level of (mandatory or voluntary) disclosure may lead to more, or to more frequent, or to more easily available information, or to a better quality of the disclosed information. In what follows, we consider all the forms of disclosure.

\section{The benefits of disclosure}

In this section, we examine why disclosure is currently desired by private actors and public authorities. What are the expected benefits for the shareholders? What are its potential contributions to social welfare?

\subsection{Benefits of disclosure for shareholders}

Disclosure, whether it is imposed on the firm by regulation or supplied voluntarily by the firm, is beneficial for shareholders if it creates value. This can come through several mechanisms.

\subsubsection{Shareholder value creation}

Most of the studies show that the increase in disclosure creates value for shareholders. This is true whatever the way disclosure is enhanced. For instance, Goncharov and al. (2006) show that German firms that comply with the regulation relating to disclosure (according to the 'comply or explain' principle) enjoy a higher share price, over a period of a year. Patel and Dallas (2002) show that a firm's disclosure (measured by Standard \& Poor's transparency score ${ }^{6}$ ) increases the price to book

\footnotetext{
${ }^{6}$ The S\&P transparency score takes into account the quantity of disclosure: the more information are given (information about ownership structure and shareholders rights, information about board and management process and financial and operational information.
} 
ratio $^{7}$. Furthermore, event studies mostly verify that disclosure creates value (Akhibe and Martin, 2006, Marquardt and Wiedman, 2007 or Ferrell, 2007), but for instance Zhang (2007) shows the existence of negative returns (meaning destruction of value). Two kinds of events are examined in the literature: the establishment of a new regulation (for example the introduction of the SarbanesOxley Act - see Akhibe and Martin, 2006 or Zhang 2007 - or the disclosure obligation introduced in 1964 in the United States by the Securities Act Amendments - see Ferrell, 2007) or spontaneous changes in firms' disclosure policy (for example the change in accounting standards, Marquardt and Wiedman, 2007).

Disclosure also creates shareholder value by allowing a firm to reduce the cost of its capital. The majority of the studies show this positive impact (Botosan, 1997 or Cheng et al., 2006). Some studies arrive at less conclusive results. For instance Botosan (2000) finds that an increased disclosure only benefits to companies that are followed by few financial analysts. Botosan and Plumlee (2002) show that a more transparent annual report decreases the cost of capital but that more frequent information given during the year increases it.

Finally, a firm can gain from its own disclosure by the additional investments that it may be able to implement. Khurana et al. (2006) show that the more transparent a firm is, the higher the part of a firm growth that is financed externally will be. The underlying idea is that disclosure facilitates external financing, investments and growth. Similarly, Utrero-Gonzalès (2006) finds that a strong regulatory requirement for disclosure leads to lower debt levels: greater disclosure would allow firms to raise equity capital more easily.

To sum up, it seems that disclosure can actually have positive effects for shareholders.

\subsubsection{Improvement in information held by third parties}

The first mechanism relates to the information held by third parties, whether it is favorable or not. More accurate forecasts by financial analysts are a proof of this (see for instance Arping and Sautner, $2010^{8}$ ). Of course, this supposes that any surplus information is correctly processed, and converted into information that is directly usable by investors. The accuracy of financial analyses can be measured, on an ex post basis, by evaluating the real profitability of shares. For example, thanks to an international comparisons, Bhat et al. (2006) show that regulations favoring disclosure improve the accuracy of forecasts, and Hope (2003) shows a positive link between the quality of financial forecasts and the degree of disclosure of annual report and a positive links between the

\footnotetext{
${ }^{7}$ The price to book ratio is the relationship between the market value and the firm's book value

${ }^{8}$ In order to know whether the Sarbanes-Oxley Act increased transparency of firms, Arping and Sautner (2010) use the forecast error and the forecast dispersion as proxies of opaqueness.
} 
quality of financial forecasts and the degree of enforcement of accountings standards.

One of the first effects of better information is the reduction in information asymmetry that prevails among investors. This asymmetry allows informed agents to make profits to the detriment of uninformed agents, through what is known as informed trading. As a consequence, market makers increase their bid-ask spread to protect themselves from informed trading. The success of disclosure can thus be claimed if it reduces the bid-ask spread, as this means a reduction of the cost of capital, which is beneficial to the firm. While initial results revealed such an impact, more recent studies do not confirm it. For example, after the introduction of Regulation Fair Disclosure in 2000, while Hasbrouck (1991) shows a reduction in the volume of informed trading, Collver (2007) gets an opposite result. The relevance (at least, the strength) of this mechanism is thus not a settled issue.

Enhancing the information received by investors in the financial market allows them to improve the quality of their expectations. The more transparent a firm is, the more actors in the market get information that is specific to the share. Variations of the price of the share thus depend less on the general market trend, and more on reasons related to the firm. Thus, the systematic risk decreases, and the cost of capital is lower. This has been empirically verified, notably by Patel and Dallas (2002): a more transparent firm benefits from a reduction in its beta. Ferrell (2007) and Lambert et al. (2007) also show that disclosure leads to a reduction in the volatility of returns. Akhigbe and Martin's (2008) analysis is more qualified, as they also observe a reduction in long-term risk, but while the total risk and the specific risk share decrease, the systematic risk doesn't. Shareholders' demand for profitability will therefore not be influenced by disclosure in the long run. On the contrary, the authors observe an increase in three types of risk in the short term: total, specific and systematic. If uncertainty is reduced in the long run, it is increased in the short term. And the beta hence, finally, the cost of capital -, increases in the short term. This result follows the idea that disclosure creates price share volatility. The fair-value principle also plays a role. For instance, the theoretical analysis by Plantin (2008) shows that the market-to-market valuation, using share pricing, and being used to price share, can increase volatility on financial markets. Here again, then, the issue is not settled and disclosure benefits not warranted.

\subsubsection{Investors' behavior and increased share liquidity}

The fall in the cost of capital is also explained by a second mechanism, namely increased share liquidity. Informed trading produces a strong variation in the share price whereas, if information is diffuse, the price variations should be smoothed out, and the market will be more liquid. Diamond and Verrecchia (1991) theoretically demonstrate that an increased degree of disclosure reduces information asymmetries and the volume of informed trading. So, disclosure increases liquidity, and 
attracts investors to the market. The market makers will therefore increase the price at which they offer the share, which leads to a fall in the cost of capital. Coates (2007) puts forward another argument when looking at the Sarbanes-Oxley Act, namely the role played by confidence: if disclosure regulation allows fraud to be reduced, investors feel more confident and become more numerous. The market becomes more liquid, which is expressed by a greater depth, and by a reduced bid-ask spread. The cost of capital thus declines.

Theoretical results are largely confirmed by empirical studies. For instance, it has been shown that the adoption of International Accounting Standards (the former name for IFRS) led to a higher volume of transactions (Leuz and Verrecchia, 2000) and other studies, such as Heflin et al. (2005) or Krishnamurti et al. (2005), show that the higher the firm's disclosure, the higher the overall liquidity of the share.

\subsubsection{Change in managerial behavior: better governance and a fall in agency costs}

A third mechanism comes through improvements in corporate governance. Hermalin and Weisbach (2007), for example, emphasize a better control of the executive management by the board, while Lambert et al. (2007) insist on better decisions taken by managers, with the due consequences on the cost of capital, if only through a reduction of the private profits extracted by the managers. The correlation between the company's cash flows and those of other firms (correlation caused in particular by attempts at concealment) is therefore reduced, and the market risk of the share and therefore the company's cost of capital are lower. According to Barlev and Haddad (2003), adopting fair value accounting norms should also help to achieve these objectives.

An empirical demonstration of the fall in agency costs is difficult, however. Studies resort to proxies, or to indirect methods. For example, Khurana et al. (2006) posit that a more transparent firm reduces its agency costs and is thus able to resort more easily to external financing. They in fact exhibit a positive link between corporate disclosure and growth in their data, which tends to prove the point.

To sum up, disclosure seems to improve the information held by participants in the financial market. The financial analyses are more accurate and information asymmetries are reduced between the firm and the third party, and between participants in the market. Decisions taken by managers are more in line with shareholders' interests. Investors are attracted, and the liquidity of the share increases. Finally, the cost of capital falls. All in all, then, an improvement of disclosure seems to create value for shareholders. However, it has to be remembered that all the theoretical links are not fully supported by empirical estimates, which may not be a problem, should positive effects exist beyond shareholders. 


\subsection{Advantages of disclosure for stakeholders}

We now consider the advantages that disclosure offers for the society at large, which come from two sources: the avoidance of financial scandals and an improvement in financial stability.

If firms become more civic minded, behave in a more socially responsible way, and if financial scandals are avoided, then disclosure can be deemed beneficial. Holder-Webb et al. (2008) try to verify this assertion. They note that the last few years have been marked by regulatory action that led to the development of corporate governance, sometimes in responses to financial incidents caused by some doubtful managerial practices. Holder-Webb and al. (2008) study the disclosure policy of a sample of 50 US firms from 2004. They find significant differences in their structure of governance. Small firms provide less information than large ones, which supply more information about their independence standards, audit committees, their management supervision systems and whistleblowing procedures. However, compared to small firms, large ones do not appear to give superior information about their environment. These results obviously raise questions that lie at the heart of most financial scandals as, in the end, firms' size matters less than respecting good governance, the latter being probably the main criterion to improve financial stability. As we have seen above, one of the main objectives of the disclosure of financial statements is to inform internal and external users on the economic and financial situation of an organization. However, famous fraud scandals (Enron, WorldCom, Global Crossing, Xerox, Adelphia, Global Crossing, Parmalat, Lucent, Tyco etc.) have eroded public confidence in financial reporting. Rezaee (2005) explains that false statements have generated losses of more than $\$ 500$ billion to investors in recent years, and that this has resulted in a loss of credibility in the financial statements. Hence, the global benefits of disclosure for avoiding financial scandals seem at least doubtful. However, audits are usually undertaken to avoid problems related to the credibility of financial statements, and, as we saw above, laws, regulations and rules have tried to enhance the quality of disclosure.

The second collective advantage of disclosure lies in the financial stability it supposedly provides. Prescott (2008) estimates that retention of information and lack of disclosure are dangerous for the stability of the system, if only because the information that concerns market security is like a public good, in that it is useful for everyone: its use by one person does not reduce its value for other users. Disclosure should thus bring benefits. There may be a perverse effect here, however: imagine that a firm voluntarily discloses some information, and that markets interpret the fact that the others do not as a bad news. In such a situation, stability may be at risk because of an increase in transparency.

The issue of financial stability leads to the problem of bank crisis and bank transparency. It appears that banking crises are less likely to happen in financial systems producing comprehensive financial 
reports characterized by disclosure: Tadesse (2005) shows that market discipline ensures the stability of the financial systems and markets in countries that adopt such reports. In a study on the banking systems of 49 countries during the 1990s, he shows that the instability of financial systems and the systemic risks are lower in countries that ensure the promotion of financial information disclosure. Giannetti (2007) and Nier (2005) comes to the same conclusions: banks that communicate more information on their assets are less likely to see their financing costs increasing; greater transparency reduces the probability of systemic banking crises thanks to a better control of bank risks by depositors. However, Cordella and Yeyati (1998) show that transparency may increase the banking sector sensitivity to systemic shocks: if banks in difficulty have suffered an exogenous shock, more information generates market reaction which can worsen the bank's situation. Hasman and Samartin (2008) also bring to light the potential negative role of disclosure during a banking crisis, mentioning the bank run on the British Northern Rock in 2007.

The banking sector is important, but corporate disclosure per se can also reduce information bubbles and help relate the valuation of the firm to its fundamental value. Disclosure can thus reward firms that go to the financial markets. Akhigbe and Martin (2008) show significant changes in the evaluation of risks following the adoption of the Sarbanes-Oxley act in the financial services sector. The authors conclude that the financial market rewards firms that are strongly transparent and that have a high level of governance, and conversely.

Over a long period, disclosure remains essential for firms that pass through the financial market and who desire stability in their results. For instance, Ferrell (2007) empirically analyzes the impact of disclosure requirements on volatility and stock market returns. The study concludes that mandatory disclosure is associated with a spectacular reduction in the global volatility of stock market returns. World Bank economists in particular have endorsed the virtues of disclosure as regards financial stability. Vishwanath and Kaufmann (1999) point out that promoting greater disclosure is directly aimed at financial stability, contributing to the development of sound institutional infrastructures, drawing up standards and reliable accounting practices, improving incentives to disclose information and reducing to the minimum perverse incentives produced by safety nets, such as deposit insurance.

All in all, then, if private gains for shareholders are sometimes doubtful (or at least not completely supported by the existing empirical analyses), the gains for the other stakeholders may prove more important, although they may only realize in the long run. 


\section{The costs of disclosure}

Some opinion polls reveal that $85 \%$ of finance directors thought that the costs of the SarbanesOxley act were higher than its benefits, even four years after its adoption. ${ }^{9}$ As such anecdotal evidence tends to confirm the doubts one can have, this section sets out the costs of disclosure.

\subsection{Practical costs}

The question is the following (see Admati and Pfleiderer, 2000): if disclosure is so positive, why do firms not engage in it always spontaneously? The sheer fact that firms have been forced to reveal information by one (or more) specific pieces of legislation is in itself revealing and allows us to think that disclosure leads to costs that the political decision-makers are more or less ready to impose on their firms (without ignoring the fact that through lobbying these can make known their (in)ability to bear these costs). The very cost of producing and disseminating information cannot be ignored. Even if the permanence of the legal obligation allows procedures to be standardized and economies of scale to be implemented, the direct cost of disclosure remains a factor. Bethel (2007) for example quotes the EDGAR information system used by the Securities and Exchange Commission (SEC), through which the equivalent of three million pages passes every day, knowing that before this system existed, every page could be obtained at a cost of $\$ 0.15$. The fact that since 2000 the SEC has moved from a periodic information system to a continuous system strengthens this trend still more. In the same way, as Coates (2007) points out, the direct costs of implementing the Sarbanes - Oxley act can seem low ( $\$ 1,000$ in 2004 for the monitoring costs required by the new institution overseeing auditors, the PCAOB), even if Zhang 2007 show that shareholders anticipated important costs of compliance to the Sarbanes - Oxley $\mathrm{Act}^{10}$. But firms do not disclose the costs involved in ensuring compliance for their documents and procedures, and the auditing costs have increased considerably since the beginning of the decade. ${ }^{11}$ The figure of 1 million auditing costs per billion of revenue is often quoted, with annual reductions (that can be attributed to initial fixed costs and to economies of scale) varying from $15 \%$ to $40 \%$. As for the indirect costs (see below: these are linked to the opportunity cost of the managers concerned, to growing risk aversion), they are more difficult to measure, even if one can think that they can disappear over time as long as the actors assimilate the rule (Verrecchia, 2001). Moreover, we can assume (as do Admati and Pfleiderer, 2000) that the more details are given by firms, the higher the

\footnotetext{
9 Among others, see: http://www2.financialexecutives.org/files/spacer.cfm?file_id=2110.

${ }^{10}$ The issue of compliance costs of the Sarbanes-Oxley Act is controversial, as illustrated by Leuz (2007).

${ }^{11}$ The reasons for this are not especially clear, whether it has to do with the passage of the Sarbanes-Oxley act or the reduction in competition following the collapse of Andersen, see e.g. Asthana et al. (2009).
} 
cost of producing the information.

To sum up, increasing the quality of the information and increasing the quantity of disclosed information generates costs of implementation, whatever we consider voluntary disclosure or mandatory disclosure, and whatever the regulation is. Moreover, the regulation may increase these costs. There is scope for regulation because the private costs of transparency are high whereas the social benefits are important: disclosure has important positive externalities, as highlighted by Arruñada (2011). For instance, the temptation to use information distributed by some firms to evaluate other firms whose activity (or value) is not necessarily correlated with the one disseminating the information, leads to an amount of information that is lower than the social optimum. Forcing firms to reveal information can be useful. However, if policymakers over-estimate social advantages, they will require too much transparency, and the level of costs will be sub-optimal. The financial industry case, studied by Akhigbe and Martin (2006) is moreover enlightening on this point. The authors study the impact of the Sarbanes-Oxley act in order to assess whether recommendations aimed at reducing the opacity of financial statements have, in net terms, been costly or beneficial. The choice of the sector studied is linked to an assessment of a higher than average opacity (see Morgan, 2002, for example). Akhigbe and Martin's estimate of gains is based on an event study. The authors show that there are wealth creation effects in the financial industry, apart from investment brokers. However, their estimates reveal that the gains are stronger when firms have good governance practices. Their results follow the idea we already mentioned above: good governance leads to a greater level of quality of the disclosed information, what is rewarded by the financial market participants.

\subsection{Unfair competition and regulatory capture}

It is difficult to define optimal rules on disclosure. Ideally, the regulation should be adapted to the firms' characteristics (i.e. size, membership of a sector and so on). Existing rules should attract firms and capital to the markets for which these rules are defined, a condition that obviously makes it more difficult to define, or even to apply. So disclosure regulation can create unfair competition and regulatory capture.

First, disclosure rules are probably not appropriate for all the companies that they cover, which increases their problematic nature as regards fair competition. Implementation of the Sarbanes-Oxley act provides a useful point of reference for analysts, and the results converge to estimate that the cost of disclosure falls more than proportionally on small and medium-sized enterprises, in view of the fixed costs to be borne to implement the procedures and publications required by the act (Holmstrom and Kaplan, 2003). Thus, both Engel et al. (2007) and Kamar et al. (2009) show that the smallest firms tend to withdraw 
their stock market listing or abandon market entrance, anticipating the costs of complying with the new regulation. However, the results relating to the influence of the law on the entry or exit of foreign firms are more ambiguous (see for example Litvak, 2007, and Doidge et al., 2010, for contrasting results). Wintoki (2007) also shows a more negative impact on small firms, young firms, those whose activity is narrower, who are facing more uncertainty, etc.

These results on the application of the Sarbanes-Oxley act agree with those obtained on the SEC's implementation of rules changing the obligations to notify transactions in the securities markets, between 1999 and 2000. It emerges from Bushee and Leuz's study (2005) that, following the introduction of new rules, smaller firms with lower external financing requirements prefer to transfer to less formal markets than to bear higher disclosure costs. In the same spirit, the results of Gomes et al. (2007) reveal an increase in the cost of capital for the smallest firms at the time of the implementation of Regulation Fair Disclosure by the SEC in 2000.

The costs of disclosure are therefore not only high, but they are unequally distributed because the smallest firms, and some sectors of activity, bear the costs more heavily. The "one size fits all" approach is probably deficient. In the same way, defining the "good" rules relating to disclosure is not simple at all, which is confirmed, for example, by Rodrigues and Stegemoller (2007). These authors analyze the rules of the SEC relating to the announcement by a listed company of the acquisition of a non-listed company. According to recommendations defined by the SEC, listed firms should communicate their acquisition strategy if the target is significant in terms of size. Even with the SEC's definition of what represents a "significant" target, the authors show that $80 \%$ of acquisitions that are not classified as significant nevertheless have significant effects on the valuation of acquiring firms.

But such a measurement of the usefulness of rules (even without mentioning the optimality) remains limited to firms and their owners. Yet if the vision is extended to all stakeholders, the definition of rules becomes still more difficult. It is well known that as transparency leads to the disclosure of information, competitors can use this strategically (see Dye, 1985), leading to an erosion of the firm's competitive advantage (Admati and Pfeiderer, 2000), and secrecy can be desirable (see for instance Prat, 2005). As Smith (2007) comments, many of the losers in the Enron affair were not shareholders of the firm, but employees, suppliers or others. The impact of the loss of firm value should not only be measured by Enron's shareholder value. Not to mention the fact that the most spectacular bankruptcies sometimes lead to intervention by the State (from the Savings and Loans yesterday to AIG today), which gives all taxpayers a vested interest in defining adequate transparency rules.

Of course, it is much easier for firms to organize themselves into lobbies to try to influence the 
definition of rules. The phenomenon of regulatory "capture" by agents who are the most concerned by its application has been known since Olson (1966). Stigler (1971) and Peltzman (1976), then, have developed the theory by integrating the diversity of interest groups, the rule becoming the outcome of the strategic game between the different groups concerned. The rule cannot therefore comply exactly with what would agree with the social optimum.

Consequently, as Mulherin (2007) notes, we must distrust the illusion of Nirvana already indicated by Demsetz (1969): we should avoid comparing a positive cost linked to regular market activity with a zero cost of government intervention. For Mulherin (2007, p. 433), this sophism is particularly likely to be present in the case of the Sarbanes-Oxley Act, which aims to resolve the agency costs of corporate governance using public agents who are apparently benevolent. The risk of regulatory capture increases the possibility, beyond the theoretical and practical difficulties already reported, that the defined rule has unexpected negative consequences, despite all the apparent good intentions. In this context, smaller firms are consistently losing in the regulatory game, which accords with Peltzman and Stigler's predictions, as the large firms are better able to organize and to influence the definition of rules than the smaller, younger firms.

\subsection{Governance costs}

The potential costs of disclosure in terms of governance and managerial behavior are also being taken into consideration in discussions. We saw above that an increase in disclosure allows a reduction in information asymmetry, and therefore agency costs. Some authors are, however, modifying this position. Coates (2007), analyzing the costs linked to the establishment of the Sarbanes-Oxley Act, suggests that the mandatory increase in disclosure involves two potential costs. On the one hand, opportunity costs are generated because of the additional time spent by managers and their teams on producing more information or information of better quality. On the other hand, greater risk aversion results from pressure to provide stricter financial standards. He nevertheless considers that these costs would only be linked to establishing the new information required, arguing that the additional attention required from managers and their teams is only necessary when new measures are implemented, and that risk aversion reduces once the degree of the increase in responsibilities has been better understood.

For some authors, the costs of governance linked to the increase in legal obligations on disclosure can go well beyond those identified by Coates (2007). Leuz et al. (2008) draw on a study analyzing the effects of the Sarbanes-Oxley Act, demonstrating that the cost resulting from it increases the tendency of managers to make their activities opaque in order to protect their private gains and to 
reduce external monitoring, in particular when the legal and regulatory protection of investors and managers is weak. Strengthening demands on disclosure even leads some firms to withdraw their stock market listing and so exempt themselves from most of the disclosure obligations - see for example Leuz et al. (2008), Coles (2008) or Coates (2007). Prat (2005) shows that the disclosure of information to a third party can reduce the agent's incentive to follow the principal's objective: disclosure, instead of reducing agency costs, increases them.

Perhaps the question is not so much one of disclosure as one of the level of disclosure. Hermalin and Weisbach $(2007,2008)$ show that there exists an optimal level of disclosure. As well as the cost of producing information, and the problem of disclosing information to competitors or to the regulator, the increase in disclosure required by the law is changing relationships between the board of directors or the supervisory board and managers and their teams. It is certain that the increase in disclosure allows the board of directors or the supervisory board to have better supervision of managers. But that can also generate reductions in profit, accelerate the turn-over in managers in an inefficient way and increase the remuneration of managers who demand compensation for a career that is more unstable because of the increase in risk. Furthermore, the risk that managers will falsify information to their advantage increases. As for the practical costs, the pernicious effects on governance are due to disclosure per se but a too demanding regulation can exacerbate the problem.

\section{The informational issues of disclosure}

As well as the costs of establishing disclosure, disclosure also raises informational costs, which are probably even more problematic with regard to the objective. The question here is about how the information received by the investor is transformed into usable knowledge, that is, knowledge that can be used to value the firm. In fact, in the end, disclosure is desirable in order to allow shareholders to exert control, by voting or by leaving, and to found their decisions about the purchasing and selling of shares. The objective of disclosure is to enable investors to value the share and to assess the firm's ability to create value. Real disclosure in such a sense is when the information provided by the company can be used by the person who receives it in daily decision-making (Fagotto et al., 2006). As will be seen, several problems can further away this objective. They can be linked to the regulation (that is to say to the way the information is required), or to the managers' behavior, or to transparency per se. 


\subsection{Fraud and concealment: when disclosure does not provide information}

The first problem is that it is not certain that disclosure, whether it is voluntary or imposed, actually provides information for the financial markets, and this for several reasons.

An important argument concerns the regulation: the mandatory disclosure does not necessarily require that the firms give the useful information to third parties. For instance, at the beginning of the century, regulation didn't demand to communicate elements that are off-balance sheet. Here appears another perverse effect of regulation, particularly striking for banks before the IFRS and before Basel II: banks were encouraged to develop their off-balance sheet activity.

Another argument concerns the managers' behavior, whatever the regulation is. Disclosing information does not mean disclosing true information. Fraud remains a threat that hangs over investors, as experiences of the last decade have shown. Referring to US cases of frauds in this period, Rezaee (2005) analyses the reasons, the means and the consequences of communicating falsified accounting documents, which in the huge majority of cases requires the collusion of leading managers and auditors (Enron being the prime example). In the case of WorldCom for example, the managers, the finance director and the auditors were complicit in publishing fraudulent accounting documents. The objective was to overestimate results, so that shares were over-valued and difficulties concealed. Responsibility is shared between "greedy" managers, "irresponsible" governance and "incompetent" auditors (Rezaee, 2005). This fraud led to the bankruptcy of WorldCom and charges against its managers. It is thus clear that imposing disclosure is not enough to avoid fraud. According to Rezaee (2005), better governance is necessary, notably with independent directors, as well as re-establishing real control by the auditors (one of the objectives of the Sarbanes-Oxley Act). Criado-Jiménez et al. (2008) study the implementation by Spanish firms of the obligation for a communication on environmental reporting. They show that the companies try to conceal information that is unfavorable to them. The more regulation requires transparency, the more companies establish concealment strategies that are complex to detect and to prove. Criado-Jiménez et al. (2008) believe that this reveals a first perverse effect of the requirement for disclosure. However, since these financial scandals, laws focus on the quality of disclosed information, and on the quality of governance (See section 1). This point - joined with the legal sanctions in case of fraud - should restrict the probability of frauds. 


\subsection{Manipulation and too much disclosure: when disclosure does not give relevant information}

It is also possible that the information the firm gives investors is not the information they need, because of the managers' behavior. As well as fraud, firms have a formidable tool in disclosure, perhaps the more pernicious because it is perfectly legal: to make the information provided unusable. How?

First by manipulating it. The first kind of manipulation, perhaps the oldest and the best known, is accounting manipulation: using accounting standards in order to reveal the most favorable balance sheet. For example, the method that consists of omitting all the unfavorable accounts and cleaning up the balance sheet, in a year in which results are poor. There are also strategies to smooth out the results. Thanks to a survey carried out amongst corporate managers, Graham et al. (2005) even show that managers go as far as sacrificing long-term profits in order to smooth out their results. The objective is to transfer information on future profits to shareholders, and to avoid price volatility. This point is extremely important: for a long time, managers have known two things. First, being completely transparent creates volatility, which is desired neither by investors nor companies. Second, being completely transparent provides less information on the firm's ability to create value than a policy of smoothing out results or dividends. Transparency can lead to information being destroyed. Moreover, investors are not misled: Lang and Lundholm (1996), using US data, show that shareholders poorly receive a sudden increase in the frequency of disclosure. In the same way, Botosan and Plumlee (2002) find that while firms' cost of capital decreases with the disclosure of annual reports as we saw earlier, it is increased by an over-active communication policy over the year. Here, the argument is simply that "too much information kills information"; more mundanely, the manager tries to "cloud the issue". Too much disclosure therefore constitutes another, perfectly legal, strategy to conceal the information. From this point of view, the requirement of "permanent information" (see above, Section 1) can be harmful.

The complexity of the information provided also allows some concealment. This is Damodaran's (2006) argument. He emphasizes the discretionary power companies have over the financial information they disclose. In particular, they can choose to make it complex and therefore difficult for investors to use. One method consists of frequently changing the accounting methods used (Damodaran however shows that the market punishes this practice). Another, which accords with the idea of too much disclosure, is to multiply the number of items appearing in the balance sheet, making it difficult to read, or to multiply very detailed and incomprehensible footnotes. Damodaran 
(2006) also considers the number of pages of the financial report to be a factor of complexity, the relevant information being more difficult to find.

However, the design of the regulation can restrict this problem. For instance, Auger and Lander (2008) think that, concerning the disclosure of off-balance activities, manipulation can be decreased if the regulation "requires firms to disclose the economic motivations for the accounting practices they adopt". Sometimes, the regulation should ask for clear and understandable information instead of detailed information.

\subsection{A decline in the level of information available: when disclosure destroys information}

The distinction between information firms provide and knowledge investors can use drives us to question the production of this knowledge. Looking at the situation from the viewpoint of the recipient of information, it would be possible to argue that more accurate information is not necessarily less costly to assimilate, even if it can be easier to decipher (see Myers and Majluf, 1984, for a discussion linked to this point). The written rules (the Plain English rules prescribed by the SEC in 1998 for example) do not necessarily lessen this problem. Some studies show that if some legal measures favoring transparency increase the dissemination of information, the quality and the quantity of the information disseminated is not necessarily improved, hence an increased cost of capital for firms and their shareholders. These studies contradicted the results we described above. See for example Ahmed and Schneible (2007) and Collver (2007).

To create knowledge, work on processing and interpretation is needed, for example to move from a 300-page financial report to expectations of price. Some actors play a particular role in this respect: financial analysts and informed agents. It is they who have the strongest incentives to look for information, as they derive a direct benefit from it: financial analysts, by selling the knowledge that they have produced and informed agents by making gains at the expense of uninformed agents.

Financial analysts play a fundamental role in producing knowledge in the financial markets. Indeed, a high number of investors, in particular small shareholders, have neither the time nor the necessary competence to interpret the raw information provided by the firm. They therefore delegate this task to financial analysts. Thus, Lang and Lundholm (1996) in particular, using US data, show that the most transparent companies are those which are monitored the most by financial analysts. As we have seen above, these companies benefit from more accurate forecasts of their result, and a lower heterogeneity between these different forecasts. The information is therefore improved. But other studies lead to a more qualified result: Tong (2007) shows that if the most transparent companies do 
indeed benefit from higher quality forecasts, they suffer from a fall in the number of analysts. Indeed, greater communication by companies reduces the incentive for financial analysts to invest in an informed way: the profitability of the investment is lower, as the information is more easily accessible. Finally, improvements in the available information which results from regulation on disclosure are weak, even zero.

Informed traders play a quite similar role: acquiring knowledge requires costly informational investment by investors. Boot and Thakor (2001) consider that, as well as viewing the information disclosed by the firm, agents can look for costly information themselves. They will only do this if they can benefit from it, thanks to a transaction at the expense of uninformed agents, i.e. those who have not made this informational investment. If firms increase their disclosure, trading with uninformed agents will be less beneficial. The incentive to look for information is therefore reduced. Finally, more disclosure leads to less available information, and therefore less information transmitted in the share price. According to Boot and Thakor (2001), it is not certain that it is in the shareholders' interest for the company to be too transparent. Verrecchia (2001) also takes up this idea. Unlike Lang and Lundholm (1996) who envisaged a representative investor, Verrecchia emphasizes the heterogeneity of participants in the market. If the cost of acquiring information is heterogeneous (because of different competences, of access to different information etc.) then Boot and Thakor's argument fully applies. Disclosure will reduce the information that is globally available; this phenomenon is reminiscent of the Grossman-Stiglitz paradox.

A similar mechanism affects market liquidity. Diamond and Verrecchia (1991), or again Heflin et al. (2005), show that disclosure increases liquidity, and so reduces the profit that market makers are hoping for. Disclosure reduces the incentive of market makers to drive the share, and can therefore reduce liquidity. Finally, the impact of disclosure on liquidity and therefore on the cost of capital is ambiguous. To conclude, we emphasize that these mechanisms are due to disclosure per se (mandatory or voluntary), whatever the regulation is and whatever the managers' behavior is. The better disclosure is, the more this perverse effect plays.

Dye (1985) suggests another argument about the role of mandatory disclosure: by imposing more detailed reporting requirements, accounting boards do not necessarily increase investors' knowledge of firms, for two reasons. First, mandatory and voluntary disclosures are sometimes substitutes, so the "amount" of information produced by "more detailed" mandatory reports may be offset by a reduction in voluntary disclosures; second, firms may be able to reveal information by their actual choice among accounting techniques so the mandatory use of a "more detailed," but uniform, accounting procedure may remove this potential source of information. 


\subsection{Distortion of available information: when disclosure increases information asymmetries}

If the transformation of information provided by the firm into usable knowledge requires time, competences and money, then corporate disclosure per se (mandatory or voluntary) may increase information asymmetries instead of reducing them. The microstructure of financial markets again provides interesting empirical elements on this point. For example, Kim and Verrecchia (1994), studying trading volumes at the time of announcements made by managers, show that this disclosure increases information asymmetries. Indeed, the announcements will be transformed into knowledge that is usable by agents capable of processing the information that they contain. The latter will transform this into private information, a source of informed trading and profits. Barron et al. (2005) confirm this result: the information announcements made by managers during the year create information asymmetry in the market. This enables to explain Botosan and Plumlee's result (2002) mentioned earlier: such announcements increase the cost of capital because they increase information asymmetry between investors. In a securitization business model, Chemla and Hennessy (2011) show that disclosure increases the informational asymmetries between informed and uninformed agents. However, this argument is valid if firms disclose numerous and complex information, and if uninformed traders do not have incentives to understand them. If firms are required to provide clear information, and to make it available to a large public, then the argument is weaker.

The role of financial analysts in the production of knowledge has another consequence: an asymmetry between large and small companies. Botosan (2000) shows that for large companies, that are already the focus of attention for several financial analysts, the strength of disclosure does not have an impact on the cost of capital. On the contrary, the gains from disclosure are highest for small firms. Analysts provide little information about them, and communicating allows them to reduce their cost of capital, because that will really provide information for the market. Gomes et al. (2007) observe an opposing result. Regulation on disclosure in the United States has created a counterproductive distortion, by prohibiting "selective communication", through the disclosure of information to certain financial analysts and institutional investors before making it publicly available. The loss of this advantage made monitoring small companies comparatively uninteresting for financial analysts. The work of financial analysts focuses more on large companies, to the detriment of small companies that, as a result, see their cost of capital increase. Once again, regulation on disclosure works to the detriment of the smallest companies. 


\subsection{Illusion of knowledge and overconfidence: when disclosure gives an impression of knowing}

Finally, it appears that corporate disclosure does not inevitably lead to shareholders having better knowledge of the company's ability to create value. It is possible that the company discloses false information, conceals important information, or manipulates information to make it more favorable. It is also possible that the company communicates very frequently and in a very complex way, to make it more difficult to interpret the information provided. Furthermore, as disclosure makes the informational investment of financial analysts and informed agents less profitable, it is possible that it reduces the information that is globally available. Finally, because of the heterogeneity of agents' ability to process information, it is possible that information asymmetries are increased between shareholders.

The fact that communication by companies does not create knowledge or even that it reduces the information available to shareholders is very pernicious. When companies do not communicate much, shareholders know that they do not have information at their disposal, and, as we have seen in particular with Boot and Thakor (2001), they will try to acquire this in a costly way. Managers will try, through credible signals like smoothing results or dividends, to supply information on future profits. But if shareholders have the impression of having information, because of an imposed or voluntary communication policy, they will be much less vigilant. They will simply have an illusion of knowledge, rather than a real knowledge. They will therefore take decisions wrongly believing that they have the relevant information. They will be overconfident: they will think that they have good share price expectations, whereas they are mistaken; they will under-estimate their capacity for error. As Tsoukas (1997) and Ripken (2007) emphasize in articles reflecting on the dangers of disclosure, too much information can reduce knowledge and understanding, and thus reduce the rationality of decisions. This excess of self-confidence by participants in the financial market fuels speculative bubbles, and destabilizes the markets, as behavioral finance shows and the current crisis illustrates. Whatever the regulation is, disclosure, far from providing the financial stability desired, can on the contrary cause crises. The quality of information can reduce this risk, but an important problem remains: the actual incentive to search for, to read and to understand information when people think they know. 


\section{Conclusion}

The aim of this article was to summarize the lessons from a expanding literature on the consequences of corporate disclosure on financial markets. Two major conclusions emerge.

Firstly, and contrary to the G20 professed confidence on the global benefits of transparency and disclosure, it should now be clear to the reader that, even for shareholders, negative elements restrict the benefits of disclosure. Setting up disclosure is costly, because to produce, certify and circulate information has a significant cost. Furthermore, small firms are probably suffering from a competitive disadvantage when it comes to implementing disclosure regulations. Finally, if the company becomes transparent, managers lose private benefits. They will therefore develop strategies to keep part of the benefits in spite of everything, making their activities opaque. In the end, thus, one can, at best, conclude ambiguously in terms of governance and optimality of management decisions.

Secondly, the other major conclusion is that it is not at all obvious that disclosure, whether mandatory or voluntary, actually increases the knowledge that economic actors have of the company. First, being transparent does not necessarily mean providing information, since third parties are not shielded from disclosures of fraudulent information or the concealment of important information. Furthermore, current regulation does not include all the data relating to the firm. Second, it is not certain that a firm will give investors the information they need to take decisions. The company can manipulate the information communicated; it can deliberately make it more complex, or it can make it very extensive and difficult to interpret. Transforming information communicated by the company into knowledge usable by investors requires a great deal of work. If disclosure makes this work less profitable for financial analysts and informed agents, it is possible that the overall knowledge of the company will be reduced. Finally, as some investors are better than others at this processing, disclosure can increase the asymmetry of information that exists among the different shareholders. What will happen if third parties do not have more information while companies display a policy of disclosure? Investors are victims of an illusion of knowledge. They think they know the company but this is not the case. They will therefore show an excess of self-confidence when deciding whether to buy or sell: they will under-estimate the probability that they are mistaken. Such behavior, far from reducing the instability of financial markets, risks increasing information bubbles, and may worsen their consequences when they burst.

However, the improvement in the quality of disclosed information, in peculiar thanks to better intern and extern control, and the enhancement of governance practices may provide a solution. The 
policymakers' emphasis on transparency thus may seem over optimistic, and at least calls for further reflection on how disclosure should be required.

\section{Acknowledgements}

The authors would like to acknowledge comments and remarks on a preceding version of the paper by Valérie Mignon, editor of the journal, and two anonymous referees. We also benefited from comments made by Jean-Baptiste Desquilbet and participants of the $27^{\text {th }}$ International Symposium on Money, Banking and Finance, of 7th «Paris Finance International Meeting 》 (AFFI \& EUROFIDAI) and 3rd work-shop EBEN France on corporate ethic; and in a seminar at the University of Lille. We also thank Céline Gainet for research assistance and the French Agence Nationale de la Recherche for its financial support.

\section{References}

Admati, A. and Pfleiderer, P., 2000. Forcing Firms to Talk: Financial Disclosure Regulation and Externalities. Review of Financial Studies 13: 479-551.

Ahmed, A. and Schneible, R., 2007. The impact of regulation fair disclosure on investors' prior information quality - evidence from an analysis of changes in trading volume and stock price reactions to earnings announcements. Journal of Corporate Finance 13: 282-299.

Akhigbe, A. and Martin, A.D., 2006. Valuation impact of Sarbanes-Oxley: Evidence from disclosure and governance within the financial services industry. Journal of Banking \& Finance 30: 989-1006.

Arruñada B., 2011. Mandatory accounting disclosure by small private companies. European Journal of Law and Economics 32:377-413

Arping, S. and Sautner, Z, 2010. Did the Sarbanes-Oxley Act of 2002 Make Firms Less Opaque? Evidence from Analyst Earnings Forecasts. Available at SSRN: http://ssrn.com/abstract=1561619 or doi: 10.2139/ssrn.1561619

Asthana, Sh., Balsam, S. and Kim, S., 2009. The Effect of Enron, Anderson and Sarbanes-Oxley on the Market for Audit Service, Journal of Accounting and Public Policy 22 (1).

Auger, K. and Lander, G., 2008. The Economic Impact of the Lack of Transparency in Financial Reporting. Atlantic Economic Journal 36: 105-116.

Barlev, B. and Haddad, J.R., 2003. Fair value accounting and the management of the firm. Critical Perspectives on Accounting 14: 383-415.

Barron, O., Harris, D. and Stanford, M., 2005. Evidence on the existence of private event-period 
information around earnings announcements. The Accounting Review 80: 403-421.

Berle, A.A. and Means, G.C., 1932. The Modern Corporation and Private Property. New York: Commerce Clearing House.

Bethel, J., 2007. Recent changes in disclosure regulation: Description and evidence. Journal of Corporate Finance 13: 335-342.

Blinder, A. S., Ehrmann M., Fratzscher M., De Haan J., Jansen D.J., 2008. Central Bank Communication and Monetary Policy: A Survey of Theory and Evidence. Journal of Economic Literature 46(4): 910-945

Boot, A.W. and Thakor, A. V., 2001. The many faces of information disclosure. Review of Financial Studies 14(4):1021-1057.

Botosan, C.A. 1997. Disclosure level and the cost of equity capital” Accounting Review, July, Vol.

72 Issue 3, p323-349

Botosan, C.A., 2000. Evidence that Greater Disclosure Lowers the Cost of Equity Capital, Journal of Applied Corporate Finance 12(4): 60-69.

Botosan, C.A. and Plumlee, M.A., 2002. A Re-examination of Disclosure Level and Expected Cost of Equity Capital. Journal of Accounting Research 40 (1): 21-40.

Bushee, B.J. and Leuz, C., 2005. Economic consequences of SEC disclosure regulation: evidence from the OTC Bulletin Board. Journal of Accounting and Economics 39: 233-264.

Bushman, R., Piotroski, J.and Smith, A., 2004. What determines corporate transparency? Journal of Accounting Research 42 (2): 207-252.

Chandler, R., 1997. Accountability and disclosure: Director's remuneration in privatized utilities. Public Money \& Management 17 (2): 43-48.

Chemla, G. and Hennessy, C.A., 2011. Privately versus Publicly Optimal skin in the game: optimal mechanism and security design. CEPR Discussion Paper, $\mathrm{n}^{\circ} 8403$

Cheng CS, D. Collins and Huang, H. H. 2006. Shareholder rights, financial disclosure and the cost of equity capital. Review of Quantitative Financial Accounting, vol. 27, p. 175-204

Coates IV, J., 2007. The Goals and Promise of the Sarbanes-Oxley Act. Journal of Economic Perspectives 21 (1): 91-116.

Cordella, T. and Yeyati E.L., 1998. Public Disclosure and Bank Failures. International Monetary Fund Staff Papers. vol.45, n¹, 110-131.

Coles, J., 2008. Disclosure policy: A discussion of Leuz, Triantis and Wang (2008) on "going dark". Journal of Accounting \& Economics 45 (2/3): 209-220.

Collver, C., 2007. Is there less informed trading after regulation fair disclosure? Journal of Corporate Finance 13: 270-281. 
Crémer, J., 1995. Arm's length relationship. Quarterly Journal of Economics 110(2), 275-295.

Criado-Jiménez, I., Fernandez-Chulian, M., Husillos-Carques, F.J.. and Larrinaga-Gonzalez, C., 2008. Compliance with Mandatory Environmental Reporting in Financial Statements: The Case of Spain (2001-2003). Journal of Business Ethics 79: 245-262.

Damodaran, A., 2006. The Value of Transparency and the Cost of Complexity. Stern School of Business, January.

Demsetz, H., 1969. Information and efficiency: another viewpoint. Journal of Law and Economics 12: $1-22$.

Diamond, D. and Verrecchia, R.E., 1991. Disclosure, liquidity and the cost of capital. Journal of Finance 46: 1325-1349.

Doidge, C., Karolyi, G.A. and Stulz, R.M., 2010. Why Do Foreign Firms Leave U.S. Equity Markets? The Journal of Finance 65(4): 1507-1553.

Dye, R. A., 985. 'Strategic accounting choice and the effects of alternative financial reporting requirements', Journal of Accounting Research 23(2), 544-574.

Engel, E., Hayes, R. M. and Wang, X., 2007. The Sarbanes-Oxley Act and firms' going-private decisions. Journal of Accounting and Economics 44 (1-2): 116-145.

Fagotto, E., Fung, A., Graham, M. and Weil, D., 2006. The Effectiveness of Regulatory Disclosure Policies. Journal of Policy Analysis and Management 25(1): 155-181.

Ferrell, A., 2007. Mandatory Disclosure and Stock Returns: Evidence from the Over-the-Counter Market. The Journal of Legal Studies 36: 213-253.

Forker, J., 1992. Corporate governance and disclosure quality. Accounting \& Business Research 22 (86): 111-124.

G20., 2007. Communiqué, Meeting of Ministers and Governors in Kleinmond, South Africa, 17-18 November.

G20., 2009. Progress Report on the economic and financial actions of the London, Washington and Pittsburgh G20 summits, Prepared by the UK chair of the G20, St. Andrews, 7 November.

Giannetti, M., 2007. Financial Liberalization and Banking Crises : The Role of Capital Inflows and Lack of Transparency. Journal of Financial Intermediation. vol.16, $\mathrm{n}^{\circ} 1$, pp. 32-63.

Goncharov, I., Werner, J. R. and Zimmermann, J., 2006. Does Compliance with the German Corporate Governance Code Have an Impact on Stock Valuation? An empirical analysis. Corporate Governance 14 (5): 432-445.

Gomes A., Gorton, G. and Madureira, L., 2007. SEC Regulation Fair Disclosure, information, and the cost of capital. Journal of Corporate Finance 13: $300-334$. 
Graham, J.R., Harvey, C. R. and Rajgopal, S., 2005. The economic implications of corporate financial reporting. Journal of Accounting and Economics 40: 3-73.

Hasman A. and Samartin M., 2008. Information Acquisition and Financial Contagion. Journal of Banking \& Finance. vol.32, pp.2136-2147.

Healy, P.M. and Palepu, K.G., 2001. Information Asymmetry, Corporate Disclosure, and the Capital Markets: A Review of the Empirical Disclosure Literature. Journal of Accounting and Economics 31: 405-440.

Heflin, F., Shaw, K. and Wild, J., 2005. Disclosure quality and market liquidity: Impact of depth quotes and order sizes. Contemporary Accounting Research 22 (4): 829-865.

Hermalin, B.E. and Weisbach, M.S., 2007. Transparency and corporate governance. NBER Working paper No. W12875

Hermalin, B.E. and Weisbach, M.S., 2008. Information disclosure and corporate governance. Fisher College of Business Working Paper No. 2008-03-016.

Hirshleifer, J., 1971. 'The private and social value of information and the reward to inventive activity', American Economic Review 61, 561-574.

Holder-Webb, L., Cohen, J., Nath, L. and Wood, D., 2008. A Survey of Governance Disclosures Among U.S. Firms. Journal of Business Ethics 83, (3): 543-563

Holmstrom, B. and Kaplan, S.N., 2003. The state of US corporate governance: What's right and what's wrong. Journal of Applied Corporate Finance 15: 8-20.

Hope, O.K. 2003. Disclosure practices, enforcement of accounting standard's and analyst forecast accuracy: an international study. Journal of Accounting Research 41: 235-273.

Jensen, M. C. and Meckling, W. H., 1976. Theory of the firm: managerial behavior, agency costs, and ownership structure. Journal of Financial Economics 3: 305-360.

Kamar, E., Karaca-Mandic, P. and Talley, E.L., 2009. Going-Private Decisions and the SarbanesOxley Act of 2002: A Cross-Country Analysis. Journal of Law, Economics and Organization 25 (1): $107-133$.

Kim, O. and Verrecchia, R., 1994. Market liquidity and volume around earnings announcements. Journal of Accounting and Economics 17: 41-67.

Khurana, I.K., Pereira, R. and Martin, X. 2006. Firm Growth and Disclosure: An Empirical Analysis. Journal of Financial and Quantitative Analysis 41 (2): 357-380.

Lambert, R., Leuz, C. and Verrecchia, R. E. (2007). Accounting Information, Disclosure, and the Cost of Capital. Journal of Accounting Research 45 (2): 385-420.

Lang, M. and Lundholm, R., 1993. Cross-Sectional Determinants of Analyst Ratings of Corporate 
Disclosures, Journal of Accounting Research 31 (2): 246-271.

Lang, M.H. and Lundholm, R.J., 1996. Corporate Disclosure Policy and Analyst Behavior. Accounting Review 71 (4): 467-492.

Leuz C., 2007. Was the Sarbanes-Oxley Act of 2002 Really This Costly? A Discussion of Evidence from Event Returns and Going-Private Decisions. Journal of Accounting and Economics 44(1-2) $146-65$.

Leuz C. and Verrechia, R.E., 2000. The economic consequences of increased disclosures. Journal of Accounting Research Vol. 36: 31-40.

Leuz, C., Triantis, A. and Wang, Y., 2008. Why do firms go dark? Causes and economic consequences of voluntary SEC deregistrations. Journal of Accounting \& Economics 45 (2/3): 181-208.

Leuz, C. and Wysocki, P.D., 2008. Economic Consequences of Financial Reporting and Disclosure Regulation: A Review and Suggestions for Future Research. SSRN Working paper. URL: http://ssrn.com/abstract=1105398.

Litvak, K., 2007. The effect of the Sarbanes-Oxley Act on non-US companies cross-listed in the US. Journal of Corporate Finance 13: 195-228.

Marquardt, C.A. and Wiedman, C.I., 2007. Economic consequences of financial reporting changes: diluted EPS and contingent convertible securities. Review of Accounting Studies 12: 487-523.

Morgan, D.P., 2002. Rating banks: Risk and uncertainty in an opaque industry. American Economic Review 92: 874-888.

Mulherin, J.H., 2007. Measuring the costs and benefits of regulation: Conceptual issues in securities markets. Journal of Corporate Finance 13: $421-437$.

Myers, S.C. and Majluf, N.S., 1984. Corporate Financing and Investment Decisions when Firms Have Information that Investors do not Have. Journal of Financial Economics. 13. 187-221.

Nier E.W., 2005. Bank Stability and Transparency. Journal of Financial Stability, vol.1, pp.342354.

Olson, M., 1966. The Logic of Collective Action, Harvard University Press.

Patel S.A. and Dallas, G., 2002. Transparency and Disclosure; Overview of Methodology and Study Results, United States, Standard \& Poor's, New York, October 2002.

Peltzman, S., 1976. Toward a more general theory of regulation. Journal of Law and Economics 19: 211-240.

Plantin, G., H. Sapra and Shin H.-S., 2008. Marking-to-Market: Panacea or Pandora's Box?. Journal of Accounting Research 46(2), 435-460.

Prat, A., 2005. 'The wrong kind of transparency', American Economic Review 95(3), 862-877. 
Prescott, E. S., 2008. Should Bank Supervisors Disclose Information About Their Banks? Economic Quarterly 94 (1): 1-16.

Rezaee, Z., 2005. Causes, consequences, and deterrence of financial statement fraud. Critical Perspectives on Accounting 16: 277-298.

Ripken, S.K., 2007. The Dangers and Drawbacks of the Disclosure Antidote: Toward a More Substantive Approach to Securities Regulation, Legal Studies Research Paper Series. Chapman University. Paper no. 2007-08

Rodrigues, U. and Stegemoller, M., 2007. An inconsistency in SEC disclosure requirements? The case of the insignificant private target. Journal of Corporate Finance 13: $251-269$.

Romano, R., 2005. The Sarbanes-Oxley Act and the making of quack corporate governance, Yale Law Journal 114 (7): 1521-1612.

Shleifer, A. and Vishny, R., 1997. A survey of corporate governance. Journal of Finance 52: 737783.

Smith, J.K., 2007. Evaluating the boundaries of SEC regulation. Journal of Corporate Finance 13: 189-194.

Stigler, G.J., 1971. The theory of economic regulation. Bell Journal of Economics and Management Science 2: 3-21.

Tadesse, S., 2005. Banking Fragility and Disclosure: International Evidence, Working Papers William Davidson Institute - University of Michigan Business School.

Tong, H., 2007. Disclosure standards and market efficiency: Evidence from analysts' forecasts. Journal of International Economics 72: 222-241.

Tsoukas, H., 1997. The tyranny of light: the temptations and the paradoxes of the information society. Futures 29: 827-843.

Verrecchia, R.E., 2001. Essays on disclosure. Journal of Accounting and Economics 32: 91-180.

Vishwanath, T. and Kaufmann, D., 1999. Towards Transparency in Finance and governance. New Approaches and Their Application to Financial Markets, The World Bank Research Observer 16 (1): 41-57.

Wintoki, M.B., 2007. Corporate boards and regulation: The effect of the Sarbanes-Oxley Act and the exchange listing requirements on firm value. Journal of Corporate Finance 13: 229-250.

Zhang, I.X., 2007. Economic consequences of the Sarbanes-Oxley Act of 2002. Journal of Accounting and Economics 44: 74-115. 